\title{
GRANTING RIGHTS TO RIVERS IN COLOMBIA
}

\section{Significance for ExtrACTIVISM and Governance}

\author{
Whitney Richardson and John-Andrew McNeish
}

\section{Introduction}

Colombian courts have issued ruling recognizing 14 distinct eco-regions as rights-holders since 2016. Ten of these rights-bearing ecosystems are river basins. According to the rulings, the rights of the rivers are to be actively protected, maintained, conserved, and restored. These cases are significant concrete manifestations of a broader trend toward assigning legal rights to nature as scientists, environmentalists, indigenous communities and policymakers have come to recognize the power of strategic litigation. To date, Colombia is the country with the largest number of nature's rights court rulings worldwide (United Nations, n.d.; Radicado, 2019; Bustos and Richardson, 2020). Similar legal cases can, however, be found across the world in countries as diverse as India and New Zealand.

In this chapter, we detail the Atrato River case, the first Colombian river to be recognized as a rights-holder by a 2016 ruling. We discuss whether it, and (by association) the others that followed, represents a convincing attempt to establish a new mode of environmental governance. The rulings were primarily issued as corrective measures to redress harms due to extractive projects, and as a means to restore and protect ecological conditions that guarantee interdependent human rights (United Nations, n.d.; Rama Judicial del Poder Público, 2019). In this chapter we explore available empirical evidence that shows how the Atrato River ruling could help to protect the river, as well as the practical challenges it has created for riverine guardianship. We also consider the value of the Atrato case as a source of inspiration for wider environmental governance and extrACTIVISM, i.e. activism opposing the impacts of resource extraction (Willow, 2018). 


\section{The Atrato River Case and Mining in the Chocó}

In 2015, the social justice research center Tierra Digna filed a tutela (a legal writ based on a claim of a breach of 'fundamental' constitutional rights) on behalf of an alliance of organizations based in Colombia's department of the Chocó. The tutela was directed against 26 responsible government agencies for failing to stop well-documented illegal mining throughout the Atrato River Basin (Defensoría del Pueblo, 2014a; Defensoría del Pueblo, 2014b; Corte Constitucional, 2016). Plaintiffs claimed that this failure had led to the systematic violation of their rights, i.e. rights to life, dignity, health, a healthy environment, freedom of movement, water, food security-and those of specially protected "ethnic" groups to autonomy, culture, and territory (Corte Constitucional, 2016).

The Chocó department sits in the northwest part of Colombia and is highly regarded for its high levels of cultural and biological diversity. Ninety-seven percent of the Chocó's residents are protected "ethnic" groups (87 percent Afro-descendant and 10 percent indigenous) (Corte Constitucional, 2016). Ninety-seven percent of the Chocó's surface area is made up of collective territories under common ownership, including 600 Afro-descendant communities governed by 70 community councils and 120 indigenous reserves including those of the Embera-Chamí, Embera-Dobida, Embera-Katío, Tule, and Wounan (Corte Constitucional, 2016; Macpherson, 2019). Furthermore, 90 percent of Chocó is protected forest-including a vast range of ecosystems, endemic species, and watersheds including the Atrato River. The Atrato River Basin spans 60 percent of the Chocó and more than fifteen rivers and 300 streams run through it. The Atrato is the longest river in Colombia and third most navigable (Macpherson, 2019).

Prior to Spanish colonization, indigenous communities in the Chocó region had a long history of artisanal gold mining. When Spain colonized Chocó in the 1500s, they trafficked enslaved Africans into the area and forced indigenous peoples to mine gold for the Spanish crown. As a result, the Chocó became the largest gold producer worldwide, yet almost all the generated wealth was exported, with little reinvestment in the area. After independence, slavery was abolished and many Afro-descendants settled along the coastal regions alongside indigenous groups. Mining remained the primary economic activity. Since then, administrative authorities have continued to receive royalties for mining concessions without reinvesting socially or environmentally, as demonstrated by the Chocós high rate of unmet basic needs and deteriorating ecological conditions (Corte Constitucional, 2016).

Today, four types of mining occur in the Chocó department: 1) artisanal mining that is carried out manually using ancestral techniques at a small scale; 2) semimechanized mining that incorporates small equipment like motor pumps, hydraulic elevators, and small dredges; 3) mechanized mining that uses backhoes, dredges, bulldozers, hoses, dump trucks, high capacity motor pumps, and toxic chemicals (particularly mercury and cyanide); and 4) mega-mining that requires a lot of land, water, and energy and includes open pit mining. Though mega-mining can pose 
grave consequences to the environment, mechanized mining is considered as the most dangerous for both humans and natural entities (Corte Constitucional, 2016).

Semi-mechanized mining in the Chocó began in the 1980s when an influx of foreign actors and armed groups-paramilitaries, BACRIM (criminal) organizations, cartels, and guerilla organizations-began illegal mining operations. These actors sought to extract gold buried in the river using high-impact equipment and toxic chemicals which are cheap and portable, and ease the process of gold extraction (Güiza and Aristizabal, 2013; Corte Constitucional, 2016). Since then, there has been a proliferation of illegal mining in the region. Drug traffickers are known to launder cocaine profits by smuggling gold in and out of Colombia, by actively taxing and coercing local governments that benefit from mining, and by running shell companies that attribute gold discoveries to fictitious mines (Tubb, 2020). According to available data, in 2011 a total of 99.2 percent of the Chocó's 527 registered Mining Production Units had no mining titles or licenses, making it the region with the highest concentration of illegal mining operations (Corte Constitucional, 2016).

The proliferation of illegal mechanized mining has caused severe socio-ecological consequences. High-impact mining has resulted in the loss and contamination of water and food supplies. It has devastated subsistence and livelihoods and gravely impacted residents' health. A resident cited in the court ruling stated, “...before mechanized mining, the river was crystalline, healthy, with clear waters, and that local populations were dedicated to fishing, agriculture and artisanal mining. These were core subsistence activities for local residents and at the center of cultural life" (Corte Constitucional, 2016, p. 70). Bereft of alternatives, many residents have had to turn to illegal mining themselves, rent land to miners, or engage in sex work (T-622/16, 2016). Loss and contamination of food and water due to high impact mining have also led to the deaths of more than 30 children, impaired child development, and caused miscarriages, skin diseases, malaria outbreaks, malnourishment, and dehydration (Corte Constitucional, 2016; Comité de Seguimiento, 2018a).

High-impact mining has also had devastating consequences for the Atrato River Basin's ecological health. The use of heavy machinery and toxic chemicals has destroyed water supplies, impairing hydrological cycles and leading to increased sedimentation. In some places, little identifiable water flow remains. Mechanized mining has destroyed habitats, leading to biodiversity loss, deforestation, and the loss of genetic diversity within species. Even if high-impact mining were to cease, toxic contamination can persist for long periods of time (Corte Constitucional, 2016). By the time the Constitutional Court ruling was issued in late 2016, ecological damage to the Atrato River Basin was estimated to cover hundreds of thousands of hectares, the full extent unknown (Corte Constitucional, 2016; Delgado-Duque, 2017; OECD, 2017).

The Court affirmed that violation of plaintiffs' rights had occurred as a result of government failure to confront the proliferation of illegal mining. As a basis to remedy these complex, interdependent issues and restore conditions that guarantee plaintiff rights, the Constitutional Court issued a set of mandates tied to 
recognizing the Atrato River Basin as a rights-holder. Among these were provisions to increase the participation of local residents in decision-making processes with implications for the health and well-being of local residents and the Atrato River Basin (Corte Constitucional, 2016; Macpherson, 2019). In this way, the Court came to strengthen legal protection for an important element of nature as a means to guarantee the human rights which rely on the Atrato's ecological health and functioning (Corte Constitucional, 2016).

The Court named the state and local community representatives to be co-guardians of the Atrato River Basin. It ordered the Presidency to assign a state official as coguardian, while plaintiffs were to elect a local Guardian as the official representative of the river. The Court also ordered plaintiffs to elect a body of River Guardianscomposed of representatives from various resident communities-and called for a Panel of Experts to assist the River Guardians and help to ensure their participation was guaranteed in all processes (Corte Constitucional, 2016).

Furthermore, the Court issued several more mandates to help cumulatively to restore conditions to guarantee plaintiffs' rights, assigning responsible authorities to each one. Orders required that assigned authorities collaboratively develop and implement 1) short-, medium-, and long-term plans to decontaminate and restore the Atrato River Basin; 2) a comprehensive plan to neutralize and eradicate illegal mining in the region within six months; and 3) a comprehensive plan to recuperate plaintiffs' traditional livelihood and subsistence models, also within six months. These action plans were to be informed by epidemiological and toxicological studies. The Court also ordered a Follow-Up Committee, led by the Attorney General of Colombia, to oversee implementation efforts and evaluate compliance. Lastly, the Court ordered the state to ensure the Intersectoral Commission for Chocó to comply with the Ombudsman's 2014 Resolution 064, which was issued to address the socio-ecological humanitarian crisis in Chocó (Corte Constitucional, 2016).

\section{A Trend towards the Rights of Nature}

In 2018, just over a year after the Constitutional Court's 2016 Atrato ruling, the Supreme Court recognized the Colombian Amazon as a rights-holder, granting the Colombian Amazon region the same rights as the Atrato River Basin. The decision came in response to a tutela made by 25 Colombian youths, arguing that government omission to combat rampant deforestation in the region exacerbated climate change and, thus, threatened their future rights contingent on a healthy environment. As background, it is important to note that, after the signing of the 2016 Peace Deal, deforestation in the Colombian Amazon increased owing to the departure of the FARC-EP (a left-wing guerrilla group) from a region that they previously controlled. In line with the Atrato decision, the Amazon decision argued that until nature's right to exist is legally recognized, human rights will remain threatened (Corte Suprema de Justicia, 2018; Bustos and Richardson, 2020).

Later in 2018, the first regional court issued a decision demanding that the Páramo de Pisba be recognized as a legal subject. Since then, many more Colombian court 
decisions have recognized other rivers and ecosystems as rights-holders. These include the La Plata River; Coello, Combeima, and Cocora Rivers; Cauca River; Pance River; Otún River; Magdalena River; and Quindío River. All of these court decisions adopted the same rights as recognized by the Atrato decision; however, each decision issued a unique set of mandates intended to guarantee nature and human rights concurrently (United Nations, n.d.; Corte Constitucional, 2019). In most cases, the court deemed nature's rights as an appropriate remedy for the conflict highlighted by the lawsuit; though, in the case of the Pance River, plaintiffs filed suit on direct behalf of the river, arguing its intrinsic rights and citing the Atrato River case as precedent (Desplazada, 2019).

The courts are not the only government body acknowledging the rights of ecosystems in Colombia. In 2019 the governors of Nariño and Boyacá departments also pledged to recognize the nature's rights in their administrative proceedings within their departments (El Gobernador del Departamento de Nariño, 2019; Gobernación de Boyacá, 2019a; Gobernación de Boyacá, 2019b). Furthermore, the Jurisdicción Especial para la Paz (Special Jurisdiction for Peace) has continued to declare nature as a silent victim of the armed conflict, demanding that nature be a subject for restitution for harms done (Jurisdicción Especial para la Paz, 2019).

While Colombian courts mobilized recognition for the rights of specific river basins and ecosystems, this personification of nature as a legal subject had prior national basis. In 2011 Colombia's Law of the Victims recognized the land as a victim of the armed conflict, legally enabling the 'land' to seek restitution for harms done (Congreso de Colombia, 2011). A year before the Atrato decision, a 2015 Constitutional Court decision called for Tayrona Park's protection because of nature's intrinsic value beyond its instrumental value, paving the way for future jurisprudence to build further on this notion (Corte Constitucional, 2015).

International jurisprudence and arguments for nature's rights have also had a direct impact on the Colombian cases. The arguments and decisions issued by Colombian courts mirror designs for nature's rights governance frameworks internationally. Of note, United States based legal scholar, Christopher Stone, issued the first developed legal argument in favor of legally recognizing nature's rights in 1972. Stone's argument called for particular governance mechanisms to help to guarantee nature's rights. Stone advocated for recognizing distinct natural entities - i.e. rivers, mountains, animals, etc.-as right-holders, to help to identify and uphold their unique interests and needs to maintain ecological health (Stone, 1972).

The Atrato decision's guardianship mechanism also drew heavily from New Zealand's co-guardianship model, which named the State and the local Maori people (The iwi) as the official representatives of the Whanganui River (Te Awa Tapua) in 2014. The Whanganui River Settlement was devised as a form of restitution for colonial harms against the local Maori. Interestingly, a clerk with the Colombian Constitutional Court had conducted research on indigenous rights in New Zealand and found similarities between the Whanganui River and Atrato River Basin cases (Magallanes, 2015; Macpherson, 2019). 
Prior to Colombian courts' recognition of nature's rights, Ecuador and Bolivia had passed nature's rights legislation. In 2008 Ecuador passed a new constitution that included the protection of the rights of nature, and in 2010 Bolivia adopted a constitution and "Law of Mother Earth" with similar protections. In these cases, nature's rights were positioned as a means to reflect indigenous cosmologies in order to advance the good life (buen vivir) and live in harmony (Sumak Kawsay) with Mother Earth (Pachamama). Such laws and promulgations have done little to change realities on the ground; both national governments have continued to move forward with an extractive agenda as their primary economic driver (Lalander, 2014). Nonetheless, the extractive agenda has more readily been challenged in court, citing nature's rights as a basis, with some wins (Kauffman and Martin, 2017).

This increased presence of ecocentrism in law can also be observed in the development of recent social theory, some of which might have played into the legal recognition of the rights of nature detailed above. In recent years, important trends have destabilized earlier anthropocentric understandings of man's domination over and separation from the natural world. Latour has, for example, influentially argued for scientific accountability to be expanded to include the human and the nonhuman (Latour and Porter, 2017). Other social theorists suggest a "post-humanist" turn aimed at further reworking our understanding of human-nature relations. Haraway (2017) suggests that we need to relearn that humans are not separate but, rather, a "companion species with a complex" assemblage of natural relations. Ingold, together with other anthropologists of the "ontological turn" (Holbraad and Pedersen, 2017), proposes the foundation of a more-than-human anthropology (Ingold, 2011). As Tsing (2017) suggests, in this anthropology we do not merely identify non-humans as static others but, instead, learn about them and ourselves in action through common activities.

Across Colombia today, proposals to recognize different forms of nature's rights remain under active consideration. In 2018, several non-governmental organizations (NGO) have filed legal petitions to recognize the rights of all rivers in Colombia (Earth Law Center et al., 2018). Perhaps most notably, in the summer of 2019 Colombian legislators proposed a constitutional amendment to include a provision which recognizes nature's rights as a whole within Article 79. Article 79 affirms the human right to a healthy environment (Lozada Vargas, n.d.).

\section{An Inspiration to Governance and ExtrACTIVISM?}

The extreme levels of natural resource extraction taking place across the globe have not only caused unprecedented environmental damage, but have also stimulated sharp political, social, and cultural conflicts.

Resource extraction has been tightly connected to the histories of human development, civilization and empire, and to the processes of modernization and expectations of modernity (Harvey, 2013). Current "extractivism" has been distinguished by its single-minded disregard for environmental consequences in favor of profit and externalization, i.e. all costs-economic, social, and 
environmental-are internalized and disproportionately borne by citizens of extraction zones (Veltamayer and Petras, 2015). The borders of far-flung extractive enclaves or sacrifice zones (Lerner, 2010) have become harder to identify, as all of nature has become a commodity and earlier geographical separations reduced by technology and the concurrent higher velocity of globalization. As extractive frontiers expand ever further across the world and encroach on urban and disenfranchised populations, soft and coercive governmentalist techniques are employed by government and industry. Hearts and minds are won over by promises of jobs, investments in local services, corporate social responsibility schemes etc. The remaining uncooperative population are forcibly controlled through technologies of social pacification, including surveillance, militarized policing, and the deployment of counter-insurgency tactics branding environmentalists and land defenders as terrorists (Dunlap, 2019).

Of equal importance to the current character of extractivism is that scholars studying the growing levels of socio-environmental conflict resulting from expanding extractive frontiers have recognized that this mindset and set of practices are not free to operate with impunity. For extraction zone residents, the battling of industrial encroachment through direct action or legal challenges, lobbying government and international organizations, multi-scale alliances, media drives and targeted campaigns have become necessary for survival. Willow (2019) captures these activities intending to question, confront and tame extractivism with an antithetical term: extrACTIVISM. Her book, Understanding ExtrActivism: Culture and Power in Natural Resources Disputes, surveys how the contemporary resource extraction industry works and the multiple responses or extrACTIVISM it inspires to "counter extractivist development and domination" (Willow, 2018, p. 3).

ExtrACTIVISM in the Atrato case was expressed by Chocó resident groups banding together with the NGO Tierra Digna to take legal action. It was their filing of the tutela that mobilized the process to confront illegal mining and government inaction (Defensoría del Pueblo, 2014a; Defensoría del Pueblo, 2014b; Corte Constitucional, 2016). The rights of nature are positioned as a transformational alternative to the proliferation of illegal mining in the Atrato River Basin (Corte Constitucional, 2016; Willow, 2018).Taking legal form, extraACTIVISM importantly also moved into the state apparatus itself.

The Colombian Constitutional Court's constitutionally assigned role is to uphold the constitutional rule of law and guarantee rights. The Constitutional Court has, however, also demonstrated a willingness to carry out this role in a manner that consistently challenges the state rather than only act in its bureaucratic defence. In the Atrato case, the Constitutional Court chose to significantly push the boundaries of existing protections. In the first move of its kind in Colombia, the Court modelled the Atrato nature's rights governance approach as a means to remedy socio-ecological problems generated by extractivism and the concomitant armed conflict. It is worth noting that-while common law systems do not have the power to establish new laws-an influential 1992 Constitutional Court decision permitted the Court to grant new rights in order to uphold existing rights, 
recognizing the need for rights to adapt to changing conditions (Corte Constitucional, 1992). By naming the Atrato River Basin as a rights-holder, the Court drew from its available juridical tools as a means to strengthen existing rights tied to a healthy environment (Corte Constitucional, 2016).

As a primary objective, the decision required the national police and armed forces to help to develop and execute a comprehensive plan to "neutralize and eradicate" illegal mining - thereby further enforcing the goals of extrACTIVISM. Recognizing the proliferation of illegal mining as the most problematic form of mining facing residents, eradication of this harmful extractivist practice is considered necessary to restore required socio-ecological conditions. However, the Court also acknowledged that legal mining could pose severe socio-ecological risks that should also be evaluated to ensure the rights of residents and the Atrato River Basin be upheld. In this way, the Court went beyond the conflict framed by the tutela lawsuit to suggest that other extractivist projects be assessed and confronted in relation to both human rights and riverine rights (Corte Constitucional, 2016).

The Court's characterization of co-guardianship between Atrato residents and the state aims to strengthen the long-neglected rights of Afro-Colombians and indigenous people in the region (Macpherson, 2019). To be considered in compliance, the ruling demands that River Guardians' participation is guaranteed in all decision-making processes and that their wishes are central to the finalized comprehensive plans established to guarantee their own rights - for example, those tied to restoring traditional livelihoods and food, conditions for health-and the rights of the Atrato simultaneously. Furthermore, the ruling and follow-up reports urge the sector to incorporate River Guardians in the planning of their defense policy and to ensure differentiation between locals engaged in illegal mining due to lack of alternatives and those higher on the criminal supply chain. The ruling and subsequent compliance reports also state that the Atrato's rights are meant to uphold the rights of Atrato residents and cannot supersede them (Corte Constitucional, 2016; Comité de Seguimiento, 2018a).

Traditionally, government agencies have focused on their specific areas of mandate without sustained coordination between them. The Court saw this as contributing to the complex socio-ecological problem and ruled to require inter-institutional collaboration on all issues under shared jurisdiction regarding the Atrato case, further arguing that all agencies must seek to uphold the rights detailed by the Constitution. Therefore, all actions required by the ruling require coordination among agencies and across regions in order to be considered in compliance (Corte Constitucional, 2016; Comité de Seguimiento, 2018a).

The Court decisions were also labelled inter comunis (between the commons), paving the way for other individuals and communities in a position similar to the plaintiffs to cite the ruling's guarantees to defend and restore their own rights as tied to nature's integral functioning (Corte Constitucional, 2016). This feature opened the door for a domino effect, giving both courts and civilians new means to confront extractivism using the court system. It is difficult to determine if this feature alone opened the door for other courts to adopt a similar framework in 
their own decisions. It has, however, certainly played a role in how courts formulate their own decisions in response to similar conflicts (United Nations, n.d.).

New lawsuits seeking to guarantee nature's rights as a means to guarantee contingent human rights continue to cite the Atrato case as precedent. Other communities in Choco are also in the process of seeking to apply the ruling's guarantees to other rivers in the region (Comité de Seguimiento, 2018b; Comité de Seguimiento, 2019; Tierra Digna, 2019).

As a form of effective resistance to ongoing extractive violence in the Atrato region, little appears to have changed on the ground. However, extrACTIVISM in the form of strategic litigation has provided an effective alternative to taking up arms, and the conceptualization of nature's rights as a tool for strategic litigation remains under active development (Comité de Seguimiento, 2019). In a country that has experienced more than 55 years of armed conflict, this is a significant development. While nature's rights have not been explicitly conceptualized as an avenue for environmental peace, Colombian nature's rights approaches can be viewed within this broader context-seeing nature as a subject of and tool for restitution.

\section{Challenges to Guardianship and Governance}

Despite the ruling's stated intentions and spreading influence, the implementation of the Atrato nature's rights governance approach has struggled to meet its stated aims. Since the ruling there have been reports of low levels of compliance with the ruling, and no sanctions of noncompliant parties have been reported. Among these myriad challenges include operationalizing co-guardianship, ongoing violence and armed conflict, inter-institutional coordination, and ongoing conflicts of interest (Comité de Seguimiento, 2018a; Comité de Seguimiento, 2018b; Comité de Seguimiento, 2019; Tierra Digna, 2019; Richardson, 2020).

The court adopted a guardianship mechanism but designed it as a shared role between an elected body of Atrato residents and the state-by contrast, for example, to designating local River Guardians as the exclusive legal guardians of the Atrato River Basin. In this shared arrangement, the Ministry of the Environment and Sustainable Development (the state guardian) was deemed responsible for coordinating inter-institutional collaboration across regions and ensuring the River Guardians' input was central to all plans ordered by the ruling (Corte Constitucional, 2016).

While co-guardianship implies shared responsibilities and powers, some power imbalances have been identified. On the one hand, state agencies receive government funding through established modes of resource allocation-for example, the National Development Plan. On the other, River Guardians are permitted to raise funds through local, national and international means. Moreover, River Guardians have become elected officials without the resources afforded elected officials, including a sustained security presence, though their work is often dangerous due to its relation to armed actors (Corte Constitucional, 2016). 
Power imbalances embedded in established governance structures remain significant challenges to the implementation of the Atrato ruling. For example, the incoming president issues a National Development Plan every four years. This plan determines the administration's priorities and economic interests, and it allocates national resources to mobilize this agenda. This process is what determines what resources are distributed, and to which ministries (Aguilar-Støen et al., 2016).

In effect, this resource distribution reflects the power inherent in a Ministry to carry out its defined agenda. Recent National Development Plans have continued to prioritize extractivist interests over environmental protection, allocating more resources to the mining agencies than, for example, the Ministry of Environment and Sustainable Development. Thus, resource allocation influences ministerial capacity to meet environmental goals and uphold the rights of residents, especially those of Afro-descendants and indigenous groups (Morales, 2017; Restrepo Botero and Peña Galeano, 2017; Paz Cardona, 2018; Diaz Parra, 2019; Pardo, 2019). Meanwhile, President Duque continues to open up land to private foreign investors (King and Wherry, 2020), and some recent Court decisions have sought to speed up mining agendas in the territories, bypassing the rights of indigenous groups to consulta previa (prior consultation) in collective territories and overturning decisions based on previous decisions stemming from prior consultation retroactively by five years (Corte Constitucional, 2018; Paz Cardona, 2020). A court decision in May 2020 cited the recent coronavirus (COVID-19) pandemic as creating conditions requiring a move to online prior consultations. Anti-extractivist campaigners have claimed that this is yet another move to weaken local rights and further speed up the process of licencing concessions (Observatorio de Derechos Territoriales de los Pueblos Indígenas, 2020).

\section{Human, Nature, and Indigeneity}

An essentialist perspective of indigenous culture can be identified in many nature's rights arguments, including the Atrato ruling (Movement Rights et al., 2015). This essentialism has been encouraged by the strategic reduction of identities by indigenous peoples themselves in order to gain recognition of their distinct identities, by similarly reductive human rights and environmental campaigns, and by particular perspectives in more-than-human theory such as Amerindian perspectivism (Vivieros de Castro, 2012). At its most narrow, this perspective depicts indigenous peoples as living in a pre-modern society that is in a pact with nature, and that is both at odds with (and seriously threatened by) cultural and territorial encroachment (Tuck and Yang, 2012; Barcan, 2019).

Through the Atrato case, an alliance of so-called "ethnic" Afro-descendant and indigenous conveyed a special relationship with the Atrato River Basin. The River provides them with all of their essential needs, including water for drinking and bathing, food, recreation, and spiritual and cultural needs. They depend on the river for their physical and spiritual sustenance, and have distinct relationships with the river not just as their ancestral territory, but as a "space to reproduce life and 
recreate culture" (Macpherson, 2019, p. 143). In this way, the claimant communities sought to emphasize that their well-being relies on the integral functioning and ecological health of the Atrato River Basin — and that they have a shared interest in protecting it (Corte Constitucional, 2016; Richardson, 2020).

The Court aimed to respect this special relationship and viewed the Atrato River Basin as an extension of these resident communities - much like the notion suggested by New Zealand's Maori who declared, I am the river, and the river is me, as well as other nature's rights legislation which claimed to reflect indigenous cosmologies (such as in Ecuador and Bolivia) (Lalander, 2014; Gudynas, 2015; Magallanes, 2015; Macpherson, 2019). Having adopted this understanding of the river as an extension of the Atrato "ethnic" residents, the Court introduced a conception of biocultural rights into Colombian jurisprudence (Bavikatte and Bennett, 2015; Corte Constitucional, 2016).

While clearly well-intended, the Court's application of the hybrid notion of biocultural rights assumes that certain perspectives exist in all indigenous and Afro-descendent Atrato communities. This assumption has positive political potential, but also some potential risks and contradictions (Offen, 2003; McNeish, 2012; Tuck and Yang, 2012; Barcan, 2019; Macpherson, 2019).

The influence of other nature's rights cases (e.g. the Whanganui case in New Zealand in particular) along with the pre-existing Colombia legislative frameworks to protect cultural diversity and biological diversity led the Court to think that a bio-cultural approach would positively afford already categorized "ethnic" communities greater political agency, by offering both nature and culture greater protection (Barcan, 2019; Macpherson, 2019; Richardson, 2020). As a tool, nature's rights when backed in practice by a model for river guardianship, were also thought to provide an additional means to confront harmful extractivist interests in addition to already available legislative tools (Alvarado and Rivas-Ramírez, 2018; Macpherson, 2019).

Indigenous and Afro-descendent organizations in the region and throughout Colombia have without exception been in strong agreement with the Court ruling on the Atrato and the idea of nature as a subject of rights (CRIC, 2017). However, drawing from earlier scholarship on the subject, Offen (2003) suggests this might also create a situation in which respect for ethnic rights becomes contractual - for example, whereby ethnic groups are made responsible for stewarding the land in exchange for territorial rights. Some comparative legal scholars (O'Donnell, 2017; MacPherson, 2019) have, however, questioned whether the formalization of the biocultural rights of the Rio Atrato might overly formalize local communities' use of and access to the river.

Essentialist attitudes toward local indigenous and Afro-descendent communities assume that these communities are only concerned with protection and an ontological connection with the river and not its practical and commercial use. As MacPherson (2019) highlights, this kind of assumption has proven problematic in many contexts, including the case of the Whanganui case in New Zealand. Maori water rights claimants before the Waitangi Tribunal expressed a desire to "walk in two worlds: to resist assimilation and protect their knowledge and law but also to 
benefit commercially from development" (Macpherson, 2019, p. 223). The way in which indigenous peoples choose to "use" natural resources might not, in fact, coincide with Western notions of indigenous culture.

Although this has so far not been an explicit problem in the Atrato River case, MacPherson asks whether such legal essentialization can cause similar complications to existing territorial claims:

We know from the legal pluralism literature that when states recognize indigenous rights and interests, there is an inevitable process of translation, accommodation and mediation. Legal personality is a mechanism used to recognise indigenous and tribal relationships and jurisdictions to manage the natural world. However, the indigenous rights are not recognized in their complete form, and are actually limited via the process of recognition. As an example of this, while the Atrato communities' biocultural rights are positioned as being territorial in nature, and although the indigenous and Afro-descendent communities successfully claimed a failure to protect their right to "territory," the Court does not recognize a right to property for the communities in the river, nor for the river to own itself.

(MacPherson, 2019, p. 156)

Such a legal reduction also presents a possible loophole through which state authorities might feasibly contest claims to territory in the interest of pursuing ongoing extractive interests in the region, thus contributing to ongoing territorial tensions. Despite outward-facing emphasis on the need to protect the Atrato River Basin and residents and the development of nature's rights as a strategic tool (while also calling into question the impact of "legal" extractive activities), the State's legal ownership over the subsoil continues to permit the State to extract nonrenewable resources for its own interests nationwide. Therefore, it is worth noting that the rhetoric surrounding upholding the rights of ethnic communities and the Atrato remain subject to legal contestation and disregard by authorities with extractive interests.

As is characteristic of reductive understandings of indigeneity and "ethnic" identities, essentialist views might contribute to an erasure of the complexity of indigenous and Afro-descendant communities and their interest in the right to not only protect, but make use of their natural wealth (Bicker et al., 2003; Hooker, 2005; Tuck and Yang, 2012; Ojulari, 2015; Blaser and de la Cadena, 2018; Barcan, 2019; Ramírez, 2019).

\section{Complex Political Ecologies: Governance in Social Minefields}

River governance of the Atrato River Basin confronts a complex political ecology. In an August 2020 conversation with John-Andrew McNeish, Ximena González, one of the founders of Tierra Digna and a lawyer behind the Atrato case, commented that it was this complex reality that posed the greatest threat and challenge to the success of the Atrato ruling and the continued work of the river guardians. 
Positioned as an "activist" decision by the Court, MacPherson questions why the unorthodox decision has not met with significant resistance by the executive government (MacPherson, 2019). Given the initial resistance of the government agencies targeted by the tutela to admitting responsibility, the same agencies have formally embraced the decision. There has been no move to nullify the decision, despite their legal ability to do so (Corte Constitucional, 2016; MacPherson, 2019). Macpherson suggests this should raise suspicion among activists and analysts that the decision and guardianship model might be "without teeth," i.e. incapable of deterring the government from its plans for economic development or holding it accountable for the river's protection in the face of its ongoing illegal use.

Gaps between alleged ambitions and effective implementation are observed in other regions claiming to seek guarantees for nature's rights. In both Ecuador and Bolivia, protections for nature's rights and concepts of buen vivir remain poorly applied, manipulated by the government and erratically implemented by the courts (Lelander, 2014). The ongoing expansion of extractive frontiers are also observed to have continued in these areas (Bury and Bebbington, 2013; Göbel and Ulloa, 2014; Revelo-Rebolledo, 2019).

A common criticism of the Río Atrato decision is that the model of river guardianship it introduces is overly ambitious, idealistic, and impractical (MacPherson, 2019). For example, effective river guardianship requires communication and collaboration across multiple riverine communities spread over a vast region with varying degrees of mobility. To succeed, river guardianship must operate across a vast and complex topography. The Atrato watershed covers 40,000 sq km and stretches 750 $\mathrm{km}$ from the Andes to the Gulf of Urabá on the Caribbean Sea, in which there is a rich but also diverse set of ecosystems. Each group and its members have diverse experiences and interests and, prior to the Atrato decision, many of these groups had limited prior communication. The river guardianship mechanism required collaboration for the first time, generating a unique opportunity for "ecopolitical imagination" at a scale previously unknown (Cagüeñas et al., 2020).

With that said, there are only fourteen official River Guardians (with equal male and female representation), representing select groups. Therefore, many interests and voices might not be part of the conversation (Comité de Seguimiento, 2018a; MacPherson, 2019). Some tensions within the group have emerged regarding conflicting interests. For example, some groups continue to have an interest in traditional mining in their territories, while others are concerned that this could prolong a problematic extractive economy (Cagüeñas et al., 2020). Disagreements and tensions within the group might prevent the formation of a unified vision for representing the Atrato River Basin and its many inhabitants.

Furthermore, each group has a unique relationship with the vast nature of this river, as the river presents itself distinctly across the breadth of the basin. As Cagüeñas, Galindo Orrego, and Rasmussen note:

Making the Atrato a subject of rights implies telling new stories, weaving new relationships and inventing practices that must arise from a close relationship 
with the nature of this river. This represents a challenge for the eco-political imagination, as it requires the creation of translation mechanisms that allow the behavior of all beings that make up the Atrato basin, both human and non-human, to be covered by the legal logic that encourages the sentence.

(Caguenas et al., 2020, p. 171)

Different components of the Atrato River Basin have often-competing interests that must be understood and represented. This task falls squarely onto the River Guardians.

It is worth emphasizing that the tutela was filed to confront a demonstrably noncompliant government body, and today compliance with the ruling remains low (Corte Constitucional, 2016). While a ruling implies required actions, disciplinary measures in the event of noncompliance must hold noncompliant actors accountable. Furthermore, to be effective, these disciplinary measures must be proportional to the impact of noncompliance, and these disciplinary measures must be issued in a timely manner to facilitate corrective measures. Early 2018 compliance updates indicate active discussions around appropriate sanctions due to low levels of compliance; however, by the 2019 report, mention of disciplinary action is weak to non-existent (Comité de Seguimiento, 2018a; Comité de Seguimiento, 2018b; Comité de Seguimiento, 2019). To date, there has been no clear indication of sanctions being issued for noncompliance.

The Atrato ruling was introduced in a region that lacks the sustained presence of the national police and security forces, and illegal armed groups have taken advantage of the security vacuum. Therefore, the implementation context is rife with conflict and room for error, risking failure to confront violence and harboring potential to increase it. To a high degree the Atrato ruling operates within what Rodríguez-Gavarito (2010) terms "social minefields."

Writing with a focus on the Colombian government's implementation of prior consultation, Rodríguez-Gavarito suggests that social minefields:

are true social fields, characterized by the features of enclave, extractive economies, which include grossly unequal power relations between companies and communities, and a limited state presence. They are minefields because they are highly risky; within this terrain, social relations are fraught with violence, suspicion dominates, and any false step can bring lethal consequences.

(Rodríguez-Garavito, 2010, p. 5)

Reflecting on the particular context of Colombia, Rodríguez-Garavito also observes that these fields of negotiation are also minefields in a very literal sense given that they correspond to territories that are in dispute that are plagued by anti-personnel mines planted by illegal, armed groups as a strategy of war and for obtaining territorial control (Rodríguez-Garavito, 2010). This analytic description can shed light on the context of the Atrato ruling. 
Violence and the threat of assassination against individuals involved in the process of confronting illegal mining remains a significant concern in the Atrato watershed, and high levels of confrontation and violence between actors in the region remain high (Comité de Seguimiento, 2018a; Comité de Seguimiento, 2018b; Friedman, 2018; Redacción Colombia, 2020, 2019; Tierra Digna, 2020). The defense sector has failed to produce concrete comprehensive plans to eradicate illegal mining. While reports indicate that security forces have "eradicated" some illegal mining machinery along the River Basin (by blowing it up), many machines have been repaired and remain in use. Those that have not been repaired have fallen into the river, causing further ecological damage. Still, indicators for total progress remain unknown and some figures submitted as evidence of compliance were inconsistent (Comité de Seguimiento, 2018a; Comité de Seguimiento, 2018b; Comité de Seguimiento, 2019).

In recent years, Colombia has had the second highest rate of assassinations against human rights and land defenders worldwide, making it an issue of particular concern to governance approaches which seek to achieve human rights and environmental goals (Global Witness, 2019). Human rights and environmental activists, indigenous and Afro-descendent leaders, receive daily threats of assassination by letter or SMS on a daily basis in Colombia. By increasing the visibility of human rights and land (or river) defenders as legal guardians of rights-bearing natural entities, the risk and threat of violence against these guardians will potentially increase (Redacción Colombia 2020, 2019). Without significant political will and backing to support these defenders, increased visibility might also become matched with a security and economic deficit, essentially immobilizing and threatening effective action.

\section{Conclusions: Possibility and Pessimism}

The Atrato River decision together with the ruling on the Whanganui River in New Zealand, represent significant developments in environmental jurisprudence, inspiring a raft of similar efforts of governance, protection, and extrACTIVISM across the world. Although of clear importance, as we have demonstrated, the existing evidence from the watershed area reveals there has, so far, been little meaningful change in the governance and socio-ecological conditions within the Atrato River Basin. We conclude this chapter observing possibilities but also with a sense of pessimism, given the complexities of the political ecology in which the ruling must function.

The Colombian state is determined to persist with a plan for economic development based largely on the extraction of natural resources despite the adverse socio-ecological impacts and increasing jurisprudence for recognizing nature's rights. Although the Atrato decision on the rights of rivers has garnered significant national and international attention as a novel approach to environmental protection, significant conflicts of interest remain cemented in local and national governance structures. The national extractive agenda continues to 
accelerate, and illegal armed actors continue to hold significant power throughout the entire watershed of the Atrato River. The River remains a minefield, both social and ecological.

While the Atrato decision has further inspired an international movement to reimagine human-nature relations and become a mechanism of extrACTIVISM, the depth and breadth of local work required to operationalize the eco-political visions and confront the magnitude of the socio-ecological devastation remain daunting barriers to achieving the stated aims of the tutela action and court decision. The value of the Atrato approach as an effective life jacket for vulnerable human and non-human natural communities remains in question, owing to a lack of political will, legal loopholes, armed illegal actors, a defense sector that defies legal norms, power imbalances, and a paradigm of governance reliant on expanding extractive frontiers.

An initial examination of the Atrato approach suggests that, although a new ecopolitical imagination has been activated, nature's rights have yet to crystalize fully in practice as a significantly different approach to environmental governance in the region. While the Atrato River now has formal rights, its health and the reliant interests of Afro-descendant and indigenous groups throughout the watershed remain in grave doubt.

\section{References}

Abate, R. (2019) Climate Change and the Voiceless: Protecting Future Generations, Wildlife, and Natural Resources. Cambridge: Cambridge University Press.

Aguilar-Støen, M., Toni, F., and Hirsch, C. (2016) 'Forest governance and REDD' in De Castro, F., Hogenboom, B., and Baud, M. (eds.) Environmental Governance in Latin America. New York, NY: Palgrave Macmillan.

Alvarado, P.A.A. and Rivas-Ramírez, D. (2018) 'A Milestone in Environmental \& Future Generations' Rights Protection: Recent Legal Developments Before the Colombian Supreme Court', Journal of Environmental Law, 30 (3), pp. 519-526.

Atapattu, S. and Schapper, A. (2019) Human Rights and the Environment: Key Issues. New York, NY: Routledge.

Barcan, R. (2019) 'The campaign for legal personhood for the Great Barrier Reef: Finding political and pedagogical value in the spectacular failure of care', Nature and Space, pp. 1-23.

Bavikatte, S.K. and Bennett, T. (2015) 'Community stewardship: The foundation of biocultural rights', Journal of Human Rights \& the Environment, 6 (1), pp. 7-29.

Bicker, A., Ellen, R., and Parkes, P. (eds) (2003) Indigenous Environmental Knowledge and its Transformations: Critical Anthropological Perspectives. Amsterdam: Overseas Publishers Association.

Blaser, M. and de la Cadena, M. (2018) 'Pluriverse: Proposals for a World of Many Worlds' in Blaser, M. and de la Cadena, M. (eds) A World of Many Worlds. Durham, NC: Duke University Press.

Bugge, H.C. (2013) 'Twelve fundamental challenges in environmental law: An introduction to the concept of rule of law for nature' in Voigt, C. (ed.) Rule of Law for Nature: New Dimensions and Ideas in Environmental Law. Cambridge: Cambridge University Press.

Burdon, P.D. (2012) 'A Theory of Earth Jurisprudence', Australian Journal of Legal Philosophy, 37 , pp. $28-60$. 
Bury, J. and Bebbington, A. (eds) (2013) Subterranean Struggles: New Dynamics of Mining, Oil, and Gas in Latin America. Austin, TX: University of Texas Press.

Bustos, C. and Richardson, W. (2020) 'Nature's Rights in Colombia: An Emerging Jurisprudence' in Zelle, A.R., Wilson, G., Adam, R., and Greene, H.F. (eds.) Earth Law: Emerging Ecocentric Law-A Guide for Practitioners. New York, NY: Wolters Kluwer.

Cagüeñas, D., Galindo Orrego, M.I., and Rasmussen, S. (2020) 'El Atrato y sus guardianes: Imaginación ecopolítica para hilar nuevos derechos [The Atrato River and Its Guardians: Ecopolitical Imagination for Weaving New Rights]', Revista Colombiana de Antropología, $56(2)$.

Chapin, M. (2003) 'A Challenge to Conservationists', World Watch. Available at: www.ques tia.com/magazine/1G1-124444744/a-challenge-to-conservationists.

Comité de Seguimiento. (2018a) Tercer Informe de Seguimiento Sentencia T-622 de 2016 [Third Follow-Up Report Ruling T-622 from 2016].

Comité de Seguimiento. (2018b) Cuarto Informe de Seguimiento Sentencia T-622 de 2016 [Fourth Follow-Up Report Ruling T-622 from 2016].

Comité de Seguimiento. (2019) Quinto Informe de Seguimiento Sentencia T-622 de 2016 [Fifth Follow-Up Report Ruling T-622 from 2016].

Congreso de Colombia. (2011) Ley 1448 de 2011 [Law 1448 of 2011]. Available at: www. unidadvictimas.gov.co/es/ley-1448-de-2011/13653.

Corte Constitucional. (1992) Case T-406/92, Estado Social de Derecho/Juez de tutela [Social Rule of Law/Judge of Tutela]. Available at: www.corteconstitucional.gov.co/rela toria/1992/t-406-92.htm.

Corte Constitucional. (2015) Case T-606/15, La Sala Sexta de Revisión de la Corte Constitucional. Available at: www.corteconstitucional.gov.co/relatoria/2015/t-606-15.htm.

Corte Constitucional. (2016) Case T-622/16, La Sala Sexta de Revisión de la Corte Constitucional. Available at: www.corteconstitucional.gov.co/relatoria/2016/t-622-16.htm.

Corte Constitucional. (2018) Case SU095/18, La Sala Plena de la Corte Constitucional. Available at: www.corteconstitucional.gov.co/relatoria/2018/SU095-18.htm.

Corte Suprema de Justicia. (2018) Case STC4360-2018, Sala de Casación Civil. Available at: http://files.harmonywithnatureun.org/uploads/upload605.pdf.

CRIC. (2017) Corte Constitucional declara río Atrato como sujeto de derechos. Available at: www.cric-colombia.org/portal/corte-constitucional-declara-al-rio-atrato-como-sujeto-dederechos.

Defensoría del Pueblo. (2014a) Crisis humanitaria en Chocó: Diagnóstico, valoración y acciones de la Defensoría del Pueblo [Humanitarian crisis in Chocó: Diagnostics, assessment and actions of the Ombudsman's Office, Bogotá.

Defensoría del Pueblo. (2014b) Resolución Defensorial No. 064: Crisis humanitaria en el Departamento del Chocó 2014 [Ombudsman Resolution No. 064: Humanitarian crisis in the Department of Chocó 2014]. Available at: www.defensoria.gov.co/es/public/resolu ciones/2552/Resolución- Defensorial-064-de-2014-Defensorial.htm.

Delgado-Duque, L. (2017) 'El papel de los grupos ambientalistas contra la minería ilegal en Chocó; más allá del lobby' ['The role of environmental groups against illegal mining in Chocó: beyond the lobby'], Revista Estrategia Organizacional, 6 (1).

Desplazada. (2019) N.U.R. 2019-00043-00, República de Colombia Juzgado Tercero de Ejecución de Penas y Medidas de Seguridad. Available at: www.desplazada.co/wp-content/up loads/2019/07/19-07-12-JUZ.-EJECUSION-DE-PENAS-Tut.-2019-00043-00-Rio-Pan ce-1.pdf.

Diaz Parra, K. (2019) Extractivismo en la brava en el Plan Nacional de Desarrollo del gobierno del Duque [Like it or not, extractivism in the National Development Plan of the Duque government], Semana Sostenible. Available at: https://sostenibilidad.semana. 
com/impacto/articulo/extractivismo-a-la-brava-en-el-plan-nacional-de-desarrollo-del-go bierno-de-duque/44087.

Dunlap, A. (2019) Renewing Destruction: Wind Energy Development in Oaxaca, Mexico. New York, NY: Rowman \& Littlefield.

Earth Law Center, International Rivers, and RIDH. (2018) Amicus Brief Urges Fundamental Rights for the Anchicaya and All Colombian Rivers. Available at: www.earthla wcenter.org/elc-in-the-news/2018/8/amicus-brief-urges-fundamental-rights-for-the-anc hicay-and-all-colombian-rivers.

Earth Law Center. (2016) 2016 Update: Fighting for Our Shared Future: Protecting Both Human Rights and Nature's Rights. Available at: www.earthlawcenter.org/co-violation s-of-rights/?utm_content=LDF\%20tweet $\% 20$ co-violations\%20report.

El Gobernador del Departamento de Nariño. (2019) Decreto No. 348 [Decree No. 348]. Available at: https://servicio.xn-nario-rta.gov.co/DespachoGobernador/Normatividad/a rchivos/Decretos/2019/Decreto-348-2019-07-15.pdf.

Friedman, J. (2018) 'The Only Protection Is God: Negotiating Faith and Violence in Chocó, The Pulitzer Center. Available at: https://pulitzercenter.org/reporting/only-p rotection-god-negotiating-faith-and-violence-choco.

Global Witness. (2019) Enemies of the State: How governments and businesses silence land and environmental defenders. Available at: www.globalwitness.org/en/campaigns/envir onmental-activists/enemies-state/.

Göbel, B. and Ulloa, A. (eds) (2014) El extractivismo minero en Colombia y América Latina. Bogota: Biblioteca Abierta.

Gobernación de Boyacá. (2019a) Boyacá Sigue Avanzando [Boyacá Moves Forward]. Available at: http://sedboyaca.gov.co/wp-content/uploads/2020/01/RamiroBarragan_Programa DeGobierno_2020-2023.pdf.

Gobernación de Boyacá. (2019b) Gobernadores de Boyacá y Nariño, reafirmando la fuerza de las regiones, firman pacto para implementación de decretos por la vida [Governors of Boyacá and Nariño, reaffirm the strength of the regions, sign pact to impact decrees for life]. Available at: www.boyaca.gov.co/gobernadores-de-boyaca-y-narino-reafirmando-la -fuerza-de-las-regiones-firman-pacto-para-implementacion-de-decretos-por-la-vida-2.

Gordon, G. (2018) 'Environmental Personhood', Columbia Journal of Environmental Law, 43 (1), pp. 49-91.

Gudynas, E. (2015) Derechos de la Naturaleza: Ética Biocéntrica y Políticas Ambientales. Buenos Aires: Tinta Limón Ediciones.

Güiza, L. and Aristizabal, J.D. (2013) 'Mercury and gold mining in Colombia: A failed state', Universitas Scientiarum, 18 (1), pp. 33-49.

Haraway, D.J. (2017) Staying with the Trouble: Making Kin in the Chthulucene. Durham, NC: Duke University Press.

Harvey, D. (2003) The New Imperialism. Oxford: Oxford University Press.

Harvey, D. (2005) A Brief History of Neoliberalism. Oxford: Oxford University Press.

Holbraad, M. and Pedersen. M. (2017) The Ontological Turn: An Anthropological Exposition. Cambridge: Cambridge University Press.

Hooker, J. (2005) 'Indigenous Inclusion/Black Exclusion: Race, Ethnicity and Multicultural Citizenship in Latin America', Journal of Latin American Studies, 37 (2), pp. 285-310.

Ingold, T. (2011) Being Alive: Essays on Movements, Knowledge and Description. Abingdon: Routledge.

Jurisdicción Especial para la Paz. (2019) Unidad de Investigación y Acusación de la JEP, "Reconoce Como Víctima Silenciosa el Medio Ambiente" [Investigation and Indictment Unit of the JEP, "Recognizes the Environment as a Silent Victim"]. Available at: www.jep. gov.co/SiteAssets/Paginas/UIA/sala-de-prensa/Comunicado\%20UIA\%20-\%20009.pdf. 
Kauffman, C.M. and Martin, P.L. (2017) 'Can Rights of Nature Make Development More Sustainable? Why Some Ecuadorian lawsuits Succeed and Others Fail', World Development, 92, pp. 130-142.

King, E. and Wherry, S. (2020) 'Colombia's Environmental Crisis Accelerates Under Duque', NACLA. Available at: https://nacla.org/news/2020/04/20/colombia-environm ental-crisis-duque.

Lalander, R. (2014) 'Rights of Nature and the Indigenous Peoples in Bolivia and Ecuador: A Straitjacket for Progressive Development Politics?', Iberoamerican Journal of Development Studies, 3 (2), pp. 148-172.

Latour, B. and Porter, C. (2017) Facing Gaia: Eight Essays on the Climatic Regime. Oxford: Polity Press.

Lerner, S. (2010) Sacrifice Zones: The Front Lines of Toxic Exposure in the United States. Cambridge, MA: MIT Press.

Lozada Vargas, J.C. and Congreso de la República de Colombia: Cámara de Representantes. (n.d.) Proyecto de Acto Legislativo "por el cual se modifica el artículo 79 de la Constitución Política de Colombia" [Legislative Act Project "to modify article 79 of the Colombian Constitution"].

Macpherson, E. (2019) 'Rivers as subjects and indigenous water rights in Colombia' in Massoud, M.F., Meierhenrich, J., and Stern, R.E. (eds.) Indigenous Water Rights in Law and Regulation: Lessons from Comparative Experience. Cambridge: Cambridge University Press.

Magallanes, C.J.I. (2015) 'Nature as an Ancestor: Two Examples of Legal Personality for Nature in New Zealand', VertigO, 22.

McNeish, J.A. (2012) 'More than Beads and Feathers: Resource Extraction and the Indigenous Challenge in Latin America', in H. Haarstad (ed), New Political Spaces in Latin American Natural Resource Governance: Studies of the Americas. New York, NY: Palgrave Macmillan.

Morales, L. (2017) 'Peace and Environmental Protection in Colombia: Proposals for Sustainable Rural Development Report', Inter-American Dialogue. Available at: www.thedialogue. org/wp-content/uploads/2017/01/Envt-Colombia-Eng_Web-Res_Final-for-web.pdf.

Movement Rights, Indigenous Environmental Network, and Global Exchange. (2015) Rights of Nature \& Mother Earth: Sowing Seeds of Resistance, Love \& Change. Oakland Movement Rights.

Neopolitanos. (n.d.) Aire de Bogotá: sujeto de derechos [Air of Bogotá: subject of rights]. Available at: https://neopolitanos.org/proyectos/aire-de-bogota-sujeto-de-derechos.

Ng'weno, B. (2008) 'Can Ethnicity Replace Race? Afro-Colombians, Indigeneity and the Colombian Multicultural State', The Journal of Latin American and Caribbean Anthropology, 12 (2), pp. 414-440.

Observatorio de Derechos Territoriales de los Pueblos Indígenas [Observatory of Territorial Rights of the Indigenous Peoples]. (2020) 'Impactos del Covid-19 en los Derechos Territoriales de los Pueblos Indígenas en Colombia' [Impacts of Covid-19 on the Territorial Rights of Indigenous Peoples in Colombia]. Available at: www.ohchr.org/Documents/ Issues/IPeoples/SR/COVID-19/IndigenousCSOs/COLOMBIA_Observator_de_Derech os_Humanoa_y_Secretar\%C3\%ADa_Técnica_Ind\%C3\%ADgena.pdf.

Ødemark, J. (2010) 'Timing Indigenous Culture and Religion: Tales of Conversion and Ecological Salvation in the Amazon' in Johnson, G. and Kraft, S.E. (eds.) Handbook of Indigenous Religion(s). Leiden: Brill.

OECD. (2017) 'Due Diligence in Colombia’s Gold Supply Chain: Gold Mining in Chocó', Available at: https://mneguidelines.oecd.org/Choco-Colombia-Gold-Baseline-EN.pdf.

Offen, K.H. (2003) 'The Territorial Turn: Making Black Territories in Pacific Colombia', Journal of Latin American Geography, 2 (1), pp. 43-73. 
Ojulari, E. (2015) 'The social construction of Afro-descendant rights in Colombia' in Contemporary Challenges in Securing Human Rights. London: Institute of Commonwealth Studies.

Pardo, A. (2019) El Plan Nacional de Desarrollo profundiza el modelo extractivista [The National Development Plan deepens the extractivist model], Razón Pública. Available at: https://razonp ublica.com/el-plan-nacional-de-desarrollo-profundiza-el-modelo-extractivista.

Paz Cardona, A.J. (2018) 'Colombia's new president faces daunting environmental challenges’, Mongabay. Available at: https://news.mongabay.com/2018/08/colombias-new-p resident-faces-daunting-environmental-challenges/.

Paz Cardona, A.J. (2020) 'For Colombia, 2019 was a year of environmental discontent', Mongabay. Available at: https://news.mongabay.com/2020/01/for-colombia-2019-was-a -year-of-environmental-discontent.

Rama Judicial del Poder Público. (2019) Radicadión 63001-2333-000-2019-00024-00, Tribunal Administrativo del Quindío Sala Cuarta de Decisión.

Ramírez, M.C. (2019) 'Militarism on the Colombian Periphery in the Context of Illegality, Counterinsurgency and the Post-Conflict', Current Anthropology, 60 (19), pp. S134-S147.

Redacción Colombia 2020. (2019). “¿Nos van a matar a todos por defender el río Atrato?”: Líder social del Chocó ["They're going to kill us for defending the Atrato River?”: social leader from Chocó]', El Espectador. Available at: www.elespectador.com/colombia2020/pais/nos-va n-matar-todos-por-defender-el-rio-atrato-lider-social-del-choco-articulo-857687/.

Restrepo Botero, D.I. and Peña Galeano, C.A. (2017) 'Territories in Dispute: Tensions between 'Extractivism', Ethnic Rights, Local Governments and the Environment in Bolivia, Colombia, Ecuador and Peru', Alternative Pathways to Sustainability, 9, pp. ] 269-290.

Revelo-Rebolledo, J. (2019) 'The Political Economy of Amazon Deforestation: Subnational Development And The Uneven Reach Of The Colombian State', PhD Dissertation, University of Pennsylvania.

Richardson, W. (2020) 'Nature's Rights in Colombia: An Exploration of Legal Efforts to Secure Justice for Humans and Nature', Master's thesis, Norwegian University of Life Sciences.

Rodríguez-Gavarito, C. (2010) 'Ethnicity.gov: Global Governance, Indigenous Peoples and the Right to Prior Consultation in Social Minefields', Indiana Journal of Global Legal Studies, 18 (1), pp. 263-305.

Rounds, K. (2019) Why Colombia's deforestation spiked after the FARC's demobilization, Colombia Reports. Available at: https://colombiareports.com/why-colombias-deforesta tion-spiked-after-the-farcs-demobilization.

Stone, C. (1972) 'Should Trees Have Standing? Towards Legal Rights for Natural Objects', Southern California Law Review, 45, pp. 450-501.

Stone, C. (2010) Should Trees Have Standing? Law, Morality, and the Environment. Oxford: Oxford University Press.

Tierra Digna. (2019) Risas, Sueños y Lamentos del Río [Laughter, Dreams and Regrets of the River]. Available at: https://tierradigna.net/pdfs/web2019.pdf.

Tsing, A. (2017) Mushroom at the End of the World: On the Possibility of Life in Capitalist Ruins. Durham, NC: Duke University Press.

Tubb, D. (2020) Shifting Livelihoods: Gold Mining and Subsistence in the Chocó, Colombia. Seattle, WA: University of Washington Press.

Tuck, E. and Yang, K.W. (2012) 'Decolonization is not a metaphor', Decolonization: Indigeneity, Education \& Society, 1 (1), pp. 1-40.

United Nations. (n.d.) Rights of Nature Law, Policy and Education, Harmony with Nature Law List. Available at: www.harmonywithnatureun.org/rightsofnature.

United Nations Environmental Program. (2019) Environmental Rule of Law: First Global Report. Available at: www.unenvironment.org/resources/assessment/environmental-rule-law-first- 
global-report\#: :text=NAIROBI\%E2\%80\%94\%2024\%20January $\% 202019 \% 20 \% \mathrm{E} 2 \% 80 \% 9$ $3 \% 20$ The,over $\% 20$ the $\% 20$ last $\% 20$ four $\% 20$ decades.

Veltamayer, H. and Petras, J. (2015) The New Extractivism: A Post-neoliberal Development Model or Imperialism of the 21st Century?London: Zed Books.

Vivieros de Castro, E. (2012) Cosmological Perspectivism in Amazonia and Elsewhere. Manchester: Journal of Ethnographic Theory.

Voigt, C. (2013) A Rule of Law for Nature: New Dimensions and Ideas in Environmental Law. Cambridge: Cambridge University Press.

Whyte, K. (2017) 'Is it colonial déjà vu? Indigenous peoples and climate injustice', in J. Adamson and M. Davis (eds), Humanities for the Environment: Integrating Knowledge, Forging New Constellations of Practice. Abingdon: Routledge.

Willow, A.J. (2019) Understanding ExtrActivism: Culture and Power in Natural Resource Disputes. Abingdon: Taylor \& Francis. 